\title{
Sharpening Characterization Through the Use of Proverb in African Literature
}

\author{
Soran Mustafa Kurdi ${ }^{1}$ \\ ${ }^{1}$ Department of English Language Teaching, Faculty of Education, Tishk International University, \\ Erbil, Iraq. \\ Email: soran.mustafa@tiu.edu.iq
}

DOI: $10.53103 /$ cjlls.v1i3.22

\begin{abstract}
African oral literature offers valuable historical insight that presents diversified perspectives of the past events and characters. Of all forms of this oral heritage, proverbs have special attributes and characteristics. The African writers have found in the sources a new enrichment of their writing; one of which is characterization. Characterization is the process by which the writer reveals the personality of a character. African proverb plays significant roles in the literary works of the writers who choose to blend their works with the touch of African oral tradition. Using two literary pieces, Wole Soyinka's Death and the King's Horseman and D.T. Tiane's Sundiata: An Epic of Old Mali, this paper addresses the significance of proverb, as an essential form of African oral heritage, in sharpening characterization.
\end{abstract}

Keywords: Characterization, Proverbs, Oral Tradition, Epic, African Literature

\section{Introduction}

The people of Africa have, for centuries, handed down from one generation to the next a tradition of oral literature in their various native languages. Oral tradition offers valuable historical insight in that they are rich tapestry of images that present simultaneously diversified perspectives of the past events, characters and episodes. The African writers have found in the sources of this oral heritage a new enrichment of their writing. Of all forms of this oral heritage, proverbs have special attributes and characteristics. African proverb plays significant roles in the literary works of writers who choose to blend their works with the touch of African oral tradition, and, as an inextricable part of African tradition, gives uniqueness and authenticity to their works. Using two literary pieces, Wole Soyinka's Death and the King's Horseman and D.T. Tiane's Sundiata: An Epic of Old Mali, this paper addresses the significance of proverb, as an essential form of African oral heritage, in sharpening characterization.

According to Harold Scheub (1985), "Oral tradition is a way of observing a society that reveals the way the community feels about itself. It preserves the cultural movements 
through time, and it does this by means of images that are often found in imaginative tales, those images embody aspects of tradition that can be expressed in no other way" (p. 4). The African oral tradition distills the essences of African people's experiences, shaping them into memorable and retrievable images. Handed down from one generation to the next, the tradition seems not to have abated in its strength. The second half of the twentieth century has seen a growing interest in the African oral literature, especially in the epic form. "In 1974, Gordon Innes published three versions of [Sundiata] in one volume where he does not hesitate to call them epics, i.e., works of literature" (Lorentzon, 2007, p. 4).

If we give a specific definition to epic, in terms of western literary canon, epic is a genre of classical poetry that has a long narrative about a serious subject. It is focused on the experiences of a hero who represents the cultural values of a race, nation, or religious group in which the hero's success or failure will determine the fate of that people or nation. Usually, the epic has a vast setting, and covers a wide geographic area, it contains superhuman feats of strength or military prowess, and gods or supernatural beings frequently take part in the action. Lacking some of the Western characteristics, African epics have some special characteristics which cannot be found in the Western classical epic. In his book on the epic in Africa, Okpewho (1992) defines the African epic:

An oral epic is fundamentally a tale about the fantastic deeds of a man or men endowed with something more than human might and operating in something larger than the normal human context and it is of significance in portraying some stage of the cultural or political development of a people. It is usually narrated or performed to the background of music by an unlettered singer working alone or with some assistance from a group of accompanists (p. 34).

Performance and background music are two special characteristics of African epic. Okpewho's view on African epic is largely echoed by John W. Johnson view. According to Johnson (1997, as cited in Lorentzon 2007, p. 5), "African Epic has three modes: the narrative, the song, and the praise-proverb mode".

In African epic, proverbs play an essential role. It is in the proverb that the ancient truth of the African culture touches contemporary experience. By studying the proverbs in an epic, we gain insight into the moral issues with which the actions of characters can be measured and evaluated.

\section{Characterization through the Use of Proverbs}

Sundiata: An Epic of Old Mali (1965) is a simple and straightforward epic, with common motifs from the oral tradition. Although, the epic relies principally on the story 
told by a griot, someone who is considered to the "repository of oral tradition," the simple tale weaves through the historical fragments trapped in images and given new context in the fictional activities. Niani (1965), a historian who translated the epic from French into English, admits that "this book is primarily the work of an obscure griot" (p. xxxiii), yet a strong sense of realism invests the imaginary character and actions, even though they are taken directly from the imaginary tale tradition. In Sundiata, ancient wisdom is carried by the proverbial expression that through constant use becomes easily remembered. When the Malinke proverb, "great trees grow slowly but they plunge their roots deep into the ground" (p. 17), is viewed in isolation, it is a tired cliché, but when it is placed into realistic contexts, like it comes in Sundiata, it becomes dynamic; it portrays the culture of the individuals who use it and gives charisma to the characters. In this instance, the proverb is used by the blacksmith while talking to Sogolon Kedjou, Sundiata's father. The proverb reveals that it is a means of communication in their culture and, at the same time, it reveals the charismatic character of both the blacksmith, who uses it, and Sogolon Kedjou, who understands it, without asking for explanation.

Proverbs have many purposes among Malinke people. With proverb, they prescribe, describe and modify the character of their people. In Sundiata, readers know that proverbs are used either by the griot, who tells the tale, or the characters among themselves.

In the scene when Sundiata and his family have left Niani and stayed with Mansa Konkon, the sorcerer king of Djedeba, the characters of both Sundiata and Manding Bori are revealed. The two boys exchange proverbs to debate Manding Bory's crush on the king's daughter:

"“Come Manding bory. If I am not mistaken, you are fond of that daughter of Mansa Konkon's.'

'Yes brother, but I would have you know that to drive a cow into the stable it is necessary to take the calf in.'

'Of course, the cow will follow the kidnapper. But take care, for if the cow is in a rage so much the worse for the kidnapper"' (Niane, 1965, p. 29).

Not until the readers had this conversation, could they see Sundiata and his brother's level of wisdom and intelligent. They are about sixteen to seventeen years old, yet they speak in proverbial expressions. Proverbs are used by adults more than teenagers, partially because using proverbs well is a skill that is developed over years. Additionally, teenagers have not mastered the patterns of metaphorical expression that are invoked in proverb use. Their ability to use proverb at this age may go back to being accompanied by adults. One of these adults that has kept company with them is their mother, Sassouma Bérété, whom we see uses proverbs in many times. Another character to whom we can attribute the two brother's wisdom and intelligent is Balla Fasseke, Sundiata's griot, who 
is older than Sundiata by more than thirteen years and has inherited his father's intelligent and wisdom. When Sundiata walks on his feet (at seven), the griot tells us that "Balla Fasseke followed [Sundiata] all the time. He was past twenty and it was he who gave the child education and instruction according to Mandingo rules of conduct" (p. 23). Balla Fasseke accompanies Sundiata till the day Sundiata and his family flee from Mali. The griot's speech, later, further explains the character of the two brothers, revealing that they have grown up in adults' company and enriched with their experience about life. After the conversation between Sundiata and Manding Bori, the griot states that "Men's wisdom is contained in proverbs and when children wield proverbs it is a sign that they have profited from adult company" (p. 29).

Another important character of the tale is Balla, Sundiata's griot, gifted to him by his father, Gnankouman Doua. The role of Bella Fasséké, as a wise man knowing how the society works, is remarkable throughout the epic. He uses proverb to shed light on the character's actions in the play. In the scene when Sundiata grows popular amongst the people, after he manages to stand up for the first time and twist the great bar of iron, the griot says, "the snake has no legs yet as swift as any other animals that has four" (p. 22). The proverb refers to Sundiata's popularity versus the gossips that Bérété tries to spread about him and his mother. Bérété, with his son holding power, does everything to take Sundiata's family away from royal power and fame. She banishes Sundiata's family to a back yard of their palace, and to ridicule them, she "allowed free passage to all those inquisitive people who wanted to see [Sundiata] that crawled at the age of seven" (p. 18). On the contrary, Sundiata and his mother have nothing to free themselves from being ridiculed. But after picking up the iron rod, Sundiata tears up a young baobab tree, carries it on his shoulders, and puts it in front of his house to his mother to pick leaves from it. From that day, Sundiata is surrounded by a group of children at the same age, from royals. Thus, the proverb refers Sundiata's popularity as "a snake with no leg," yet travels as swift as any other animal "with four legs," which indicates Bérété's gossip.

African proverbs are not confined in the work of the oral form of literature as we see in the epic of Sundiata: An Epic of Old Mali. Asika (2012) in an essay about the significance of proverb in African written literature writes that "proverbs have become a tool which African writers use to justify the actions of characters, criticize bad ethical and immoral behaviors. Through the use of proverbs, African writers try to express the wealth of philosophy: wisdom and perception of life as they affect and control their communities" (p. 16). By incorporating proverbs, African writers succeed in giving their works a touch of African beauty and it helps them to enhance the plot of their stories, sharpen their characterization.

Wole Soyinka (2013), the Nigerian playwright and poet, uses proverb in his play, Death and the King's Horseman, to a great extent. This is what marks him out and makes him distinct and peculiar from his literary community. 
Soyinka was born into a Yoruba family. Yoruba people have preserved their history in their oral traditions. Abayomi (2014), in his article "Philosophical Significance of Yoruba People," highlights that Yoruba proverbs have special attributes and characteristics, which make them particularly unique and special. To him, this uniqueness comes from the fact that proverbs are handed down from one generation to another as truthful saying having been tested by usage. As such information, ideas and thoughts obtained from them would be more reliable than those gathered from other oral literatures (p. 2, 6). Richards (2003), in his essay, "Death and the King's Horseman and the Masks of Language," refers to that how Soyinka's use of proverb takes shape from the Yoruba values. He writes "The rhetorical force of the proverbs in Soyinka's play ... directs the reader back again to the social matrix from which the proverb originated" (p. 196).

Soyinka is a master and an expert in the language and traditional culture of Yoruba people. He has successfully incorporated proverb into Death and the King's Horseman. His use of proverb in the play is very profound, intelligent and serves as a trademark on Death and the King's Horseman as an African literature. A justification of this view could be clearly seen in the use of the following proverb, when at prison Elesin tells Iyaloja that it is her that renewed his tie to earth, in another word, it was Iyaloja who agrees to give her daughter to Elesin, to marry, but Iyaloja replies, "the river is never so high that the eyes of a fish are covered" (p. 56). The fish can always see what is going on regardless of how much water is in the river. Likewise, no matter how earthy tie may distract Elesin or no matter how his love for his new wife makes life sweeter for him, this should not make him forget the importance of his mission as a king's horseman. Soyinka's masterful use of the proverb in the context, gives a beautiful and artistic form to the proverb. As it is clear from the above proverb, Soyinka uses the proverbs not only to add touches of local people, but also to sharpen characterization. As a dramatist, he put all his words into the mouths of his characters.

Talking about characterization, the personalities of Soyinka's characters are often clearly defined by the proverbs they use. The proverbs in Soyinka's Death and the King's Horseman come to serve in two ways: they reveal the personality of the characters who use the proverbs and they reveal the personality of the characters to whom the proverbs are directed. In either instance, the audience is the beneficiary of nuances of character that are specifically accented by the proverb.

Almost every character in Death and the King's Horseman at some point uses traditional Yoruba proverbs. They employ Yoruba proverbs primarily as a means of bolstering their opinions and persuading others to take their point of view. The Praisesinger feels that it is his duty to remind Elesin that he is going to leave this world soon and follows his ancestors "because the man approaches a brand-new bride, he forgets the long faithful mother of his children (p. 5). Some proverbs, such as the mentioned one, have both a literal and a figurative meaning either of which must make sense. For more often proverbs 
have but one of the two. The above proverb could convey the literal meaning; Elesin, while sees the young girl in the market, forgets about his old wife, the mother of Olunde. Or, it could convey the figurative meaning that Elesin leaves this worldly life and follows his ancestors in the other life. In the proverb, not only the praise-singer's character, as a reminder, is revealed but also Elesin's. Elesin is the major character of the play. His reputation as a great and honorable man is revealed, and his immediate future is gradually unfolded. The word "Elesin" means "horseman," and "Oba" means "king," for Elesin Oba, the horseman of the king, his royal title is also his name. The king has died, and it is Elesin's duty to follow the king in death to the world of the ancestors.

As a confirmation to the Praise-singer's reminding lines, that Elesin should not forget his important mission because of his new wife, Elesin himself uses a proverb to explain that he is going to comply with their ritual and thus join the ancestors, "the kite makes for wide spaces and the wind creeps up behind its tail; can the kite say less than thank you, the quicker the better?" (p. 33) Here, Elesin refers to himself as a "kite" that is ready to fly, in other words, he is ready to make his suicide in order his soul to fly and join his ancestors. He, also, refers to the praise-singer and the people as "the wind behind its tale" to make him fulfill the mission quicker. By saying "can the kite say less than thank you," Elesin means he wants to stay a little longer to express his thanks to them. In the Elesin's proverb, the reader understands that Elesin is well-understood that he feels responsible to fulfill his duty. At the same time, the reader knows that Elesin longs to stay rather than to join his ancestors, but he justifies his stay by saying that he wants to express his thanks to them.

There is another character in the play that uses proverb predominantly, Iyaloja. She is one of the major characters in the play. She is the most powerful of the market women and regarded by them as the matriarch, the upholder of Yoruba values. In the following lines, the powerfulness of Iyaloja is revealed as the reader sees her scolding Elesin in his cowardice of defiling the rituals of his suicide, in spite of his high social status as the king's horseman. She says "how boldly the lizard struts before the pigeon when it was the eagle itself, he promised us he would confront (p. 55). In this proverb, Iyaloja indicts Elesin for making himself busy with something much less important than the thing he has promised to do. Here, the "eagle" represents Elesin's mission, which is something considered to be very important to be fulfilled by Elesin, and the "lizard" represents Pilking's deterrence of Elesin from fulfilling his mission. In Iyaloja's eyes, Elesin should commit his suicide, which is indicated by confronting the "eagle", not being challenged by Pilking, the "lizard." Figuratively, the proverb may also mean that Elesin lowers himself while he has promised the people to fly high. Again, Iyaloja harasses Elesin in proverb, while he is imprisoned, for failing to complete his role within the ritual:

We said you were the hunter returning home in triumph, a slain buffalo 
pressing down on his neck; you said wait, I first must turn up this cricket hole with my toes... We said, the dew on earth's surface was for you to wash your feet along the slopes of honor. You said No, I shall step in the vomit of cats and droppings of mice; I shall fight them for the left-overs of the world (Soyinka, 2013, p. 56).

This is a colorful language. Its primary function is to display Iyaloja's flair for expressing wisdom. No wonder she is the most powerful women in the market; she uses her power in using the beautiful language of proverbs. She reprimands Elesin boldly, yet, modestly, expresses that he did not fulfill what he was expected to do, instead he played with a "cricket's hole," stepped in "the vomits of cats and droppings of mice," and chose to be the "eaters of left- overs of the world" (p. 50). All These proverbial expressions indicate that Elesin lowered himself by choosing the life on the earth over the life on the otherworld.

\section{Conclusion}

The similarity of the language between the two texts discussed in this paper might suggest the influence of proverb as an element of language that reveals a lot about society's culture. Nothing defines a culture as distinctly as its language, and the element of language that best encapsulates a society's values and beliefs is its proverbs. Proverbs are capsules that contain highly condensed bits of a culture's values and beliefs. The use of proverb in Sundiata shows the importance of this form of oral tradition of Mande culture. The epic is about Sundiata king who founded the Empire of Mali. According to historical records, the empire was founded in the first half of the 13th century, specifically 1235 AD. This underpins that the use of proverbs has been prevalent in Africa since this time, if not before that. Passed on from generation to another for centuries, they are still in wide use today.

Wole Soyinka's Death and the King's Horseman, written in 1975, is an example of the presence of proverb in these days Africa. His use of proverbs is twofold: it highlights the rich culture of the people on which he writes as reflected in the individual traits of the characters, and it sheds a sharp light on the fact that he is an expert in the language and traditional culture of his people, Yoruba.

In brief, the African oral tradition distills the essences of the African people's experience. This tradition is part of what makes African literature great. Through the use of proverbs, African writers try to express the wealth of wisdom of life as it affects their communities. The use of proverb is a continuation and linkage between the past which brings the present to them. Sundiata: An Epic of Old Mali is an example of this linkage. Death and the King's Horseman shows how the African writers, through incorporating proverb, give their works a touch of African beauty and that helps them to enhance the plot of their stories, sharpen their characterization. This local touch of beauty has made African 
literature stand out among the literature of all other continents.

\section{References}

Abayomi, O. (2014) Philosophical significance of Yoruba people. academia.edu. Academia.edu. Retrieved from https://www.academia.edu/3397082/Philosophical_Significance_of_Yoruba_Pro verbs

Asika, I. E. (2012). Telling the African side of the story: Proverb as a crucial element in Uchenna Nwosu's the Rejected Stone. Unizik Journal of Arts and Humanities, 13(1), 14-33.

Lorentzon, L. (2007). Is African oral literature literature? Research in African Literatures, 38(3).

Niane, D.T. (1965). Sundiata: An epic of old Mali. England: Longman Group Ltd.

Okpewho, I. (1992). African oral literature: Backgrounds, character and continuity. Bloomington: Indiana.

Richards, D., \& Gikandi, S. (Eds). (2003). Death and king's horseman and the masks of language. New York: W.W. Norton \& Company, Inc.

Scheub, H. (1985). A review of African oral traditions and literature. African Studies Review, 28(2/3), 1-72. https://doi.org/10.2307/524603

Soyinka, W. (2013). Death and the king's horseman. Ed. Simon Gikandi. New York: W.W. Norton \& Company, Inc.

Virginia Department of Education Prince. (n.d). Mali: ancient crossroads of Africa Retrieved from https://www.doe.virginia.gov/instruction/history/mali/index.shtml 